\title{
T-SCAN III SYSTEM DIAGNOSTIC TOOL FOR DIGITAL OCCLUSAL ANALYSIS IN ORTHODONTICS - A MODERN APPROACH
}

\author{
Vesna Trpevska ${ }^{1}$, Gordana Kovacevska ${ }^{2}$, Alberto Benedeti ${ }^{3}$, Bozidar Jordanov ${ }^{4}$ \\ ${ }^{1}$ PHO Dental Clinical Center Sv. Pantelejmon, Clinic for Orthodontics, Skopje, R. Macedonia \\ ${ }^{2}$ Faculty of Dental Medicine, University Ss. Ciril and Metodius, Department of Prosthodontics, \\ Skopje, R. Macedonia \\ ${ }^{3}$ Faculty of Dental Medicine, University Ss. Ciril and Metodius, PHO Dental Clinical Centar for \\ Maxillofacial Surgery, Skopje, R. Macedonia \\ ${ }^{4}$ Facultu of Dental Medicine, Department for Prosthodontics, University of Dental Medicine, \\ Sofia, R. Bulgaria
}

Corresponding Author: Gordana Kovacevska, Faculty of Dental Medicine Prosthodontics Department, Vodnjanska 17, 1000 Skopje, R. Macedonia, Tel: + 389 (0)2 0706767 00, E-mail: g_kovacevska@hotmail.com

\begin{abstract}
Introduction: This systematic literature review was performed to establish the mechanism, methodology, characteristics, clinical application and opportunities of the T-Scan III System as a diagnostic tool for digital occlusal analysis in different fields of dentistry, precisely in orthodontics.

Methods: Searching of electronic databases, using MEDLINE and PubMed, hand searching of relevant key journals, and screening of reference lists of included studies with no language restriction was performed. Publications providing statistically examined data were included for systematic review.

Results: Twenty potentially relevant Randomized Controlled Trials (RCTs) were identified. Only ten met the inclusion criteria. The literature demonstrates that using digital occlusal analysis with T-Scan III System in orthodontics has significant advantage with regard to the capability of measuring occlusal parameters in static positions and during dynamic of the mandible.

Conclusion: Within the scope of this systematic review, there is evidence to support that T-Scan system is rapid and accurate in identifying the distribution of the tooth contacts and it shows great promise as a clinical diagnostic screening device for occlusion and for improving the occlusion after various dental treatments. Additional clinical studies are required to advance the indication filed of this system. Importance of using digital occlusal T-Scan analysis in orthodontics deserves further investigation.
\end{abstract}

Key words: Orthodontic treatment, skeletal orofacial anomalies, T-Scan III system, digital occlusal analysis.

\section{Introduction}

Using occlusal analysis in orthodontics is crucial. The primary goal of any orthodontic treatment is to achieve the ideal alignment between the teeth in the dental arch and the teeth antagonists [1-3], achieving Angel Class I occlusion between the canines and molars and neuromuscular balance as the final goal of the orthodontic treatment $[1,2]$. During orthodontic treatment for achieving normal (ideal) occlusion from an aesthetic and functional aspect and achieving satisfactory mastication, teeth movements and changes in the growth of facial and cranial structures can be performed.
Proper orthodontic treatment of skeletal dentofacial irregularities cannot be initiated until the correct diagnosis is given. A very important factor in establishing the diagnosis in orthodontic anomalies is detecting occlusal parameters. Numerous studies show that conventional methods do not quantify dimensional occlusal force. By contrast, digital occlusal analysis in the diagnosis enables us to obtain information on the type of occlusal interference and its relationship to symptoms of TMJ disorders [4]. The purpose of this paper is to show the importance of using digital occlusal T-Scan analysis in orthodontics. 


\section{Occlusal analysis with the T-Scan system}

\section{Relevance and state of the problem}

with reference to previous research

Despite the evolution of computer technology and the era of modern dental materials, we still come across a routine use of traditional methods in cases of occlusion analysis. Although most dentists stress the importance of occlusion, the highest percentage of occlusal contacts evaluation is still based on articulation paper, wax and silicone tables. The T-Scan III Computerized Occlusal Analysis System (Tekscan Inc., South Boston, MA USA), (Fig. 1), exceeds the limitations of using articulation paper. It provides analysis of relative occlusal forces that are recorded using the intraoral pressure sensor and displays occlusal forces to minimize the possibility of repeating mistakes when occlusion is examined by articulation paper and it depends on the subjective feelings of the patient. Studies show that for a dentist using articulation paper it is very difficult to accurately determine which occlusal contact receives more force. During intercuspidation, time and force are the main occlusal factors measured with the T-Scan system. Thanks to the T-Scan system, which displays all the measured numerous occlusal contacts for further dynamic analysis, today we can successfully treat many occlusal problems and provide the patient with high quality occlusion at the end of the treatment [5].

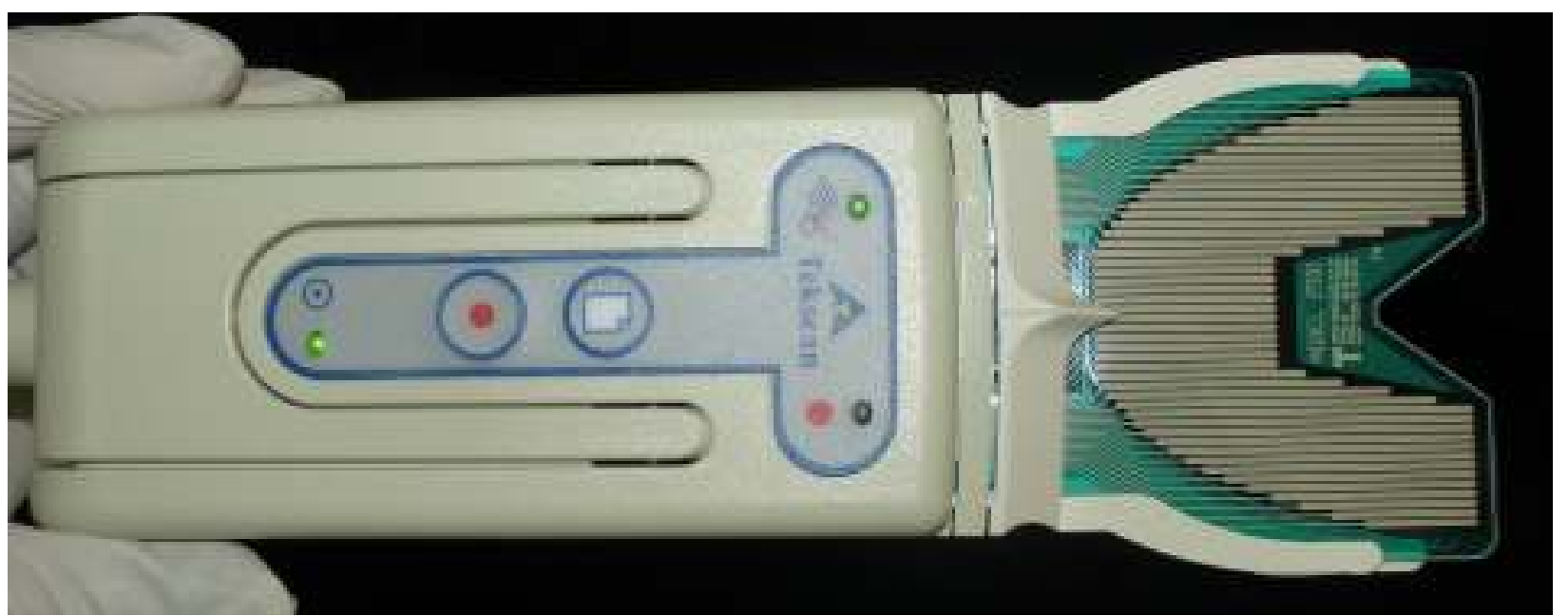

Figure 1 - T-Scan III handler connected directly through USB to the computer and sensor-100 microns thickness

In orthodontics, starting from the fact that good occlusal contacts are essential in maintaining dental health and ensuring stable long-term results, special attention is paid to achieving normal occlusion [1]. In agreement with our patients, we took photographs where we noticed the absence of the upper left canine due to impaction. The absence of a tooth in the dental arch leads to the appearance of mastication disability, which if not followed by restoration of teeth within a certain period of time leads to displacement of teeth, loss of balance and consequently complete morphological, functional and aesthetic complications in the orofacial system (Fig. 2).

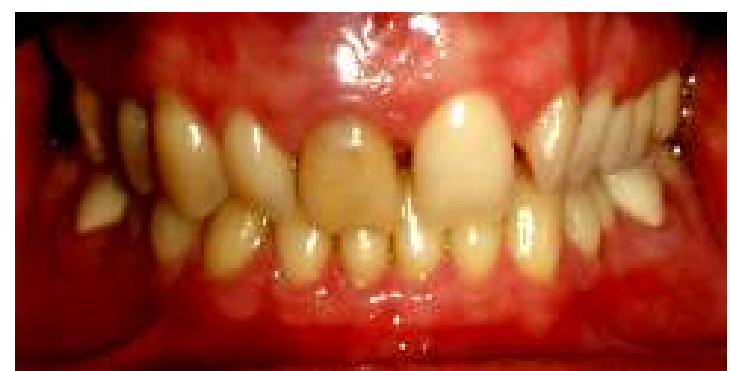

Figure 2-Patient E. T., intraoral view in central occlusion
In addition to the possibility of occlusal diagnostics (Fig. 3), this system is helpful when it comes to how the patient understands his occlusion situation from an aesthetic and functional aspect. The subjects were seated in an upright position in a dental chair with the Frankfort plane parallel to the floor. All recordings were made by the same operator to avoid possible variation. The T-Scan III sensor was placed between the upper central incisors, parallel with the occlusal plane.

The graphic presentation of the T-Scan system is not only easy for the therapist to understand, it is also an auxiliary tool through which the patient's visualization is facilitated and it is easier to understand the nature and extent of his occlusal disharmony [6].

As an innovation on the market, the T-Scan system goes back about 25 years. The first T-Scan I system was designed in 1987 and since then, with specified contemporary technical advancements and whole system revisions and their upgrades, the T-Scan III system version 7.0 has been designed, the results of which are independent from the operator. 


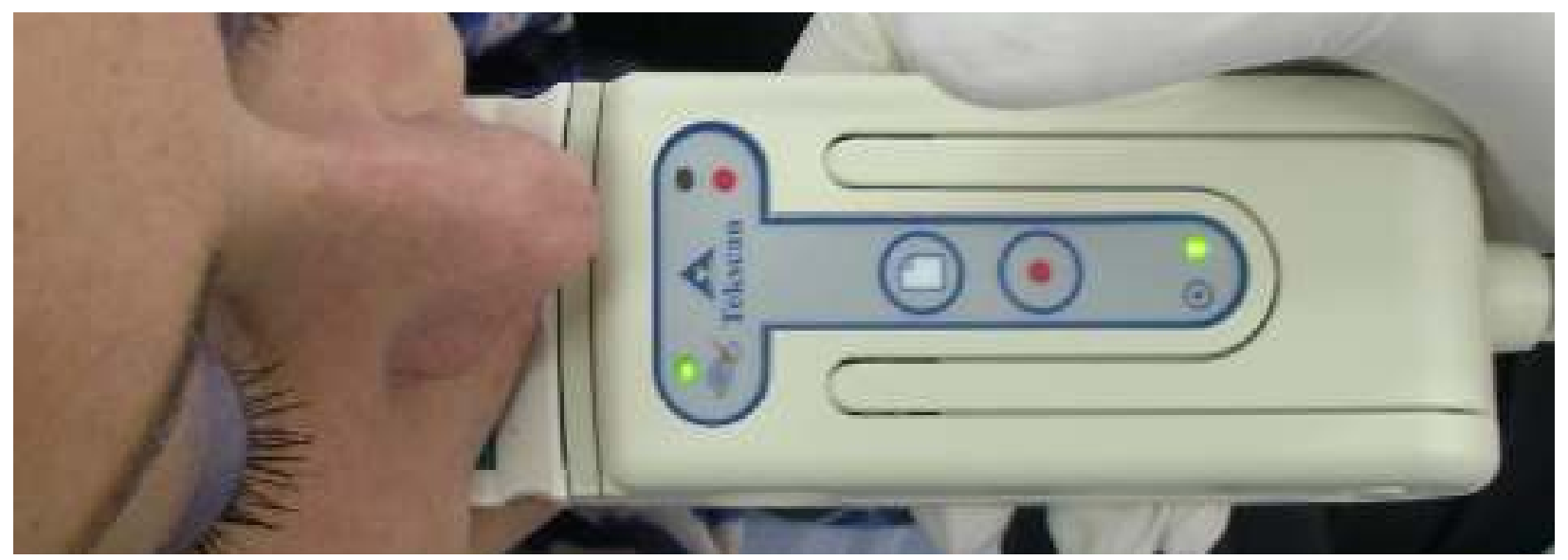

Figure 3 - T-Scan III - the sensor is placed between central incisors, parallel with occlusal plane The development of the T-Scan system

The T-Scan III system enables static and dynamic digital analysis of occlusion in unit time and recording of the distribution of occlusal forces in dental arches in different clinical situations [6].

In the left top corner analysis window, the amount of relative occlusal force is displayed in 3dimensional coloured bar graphs. The colour and height of each bar indicates the intensity of force per contact. The top right corner analysis window is a 2-dimensional dental arch in which the occlusal contact forces are surrounded by a yellow outline that locates the contacts, while illustrating in the same colours (as the 3-dimensional bar graph window) the differing occlusal force levels.

The two lower windows are the "Force vs. Time" graphs. They illustrate changing occlusal force percentages across time, in both the left arch half (green line) and the right arch half (red line). The horizontal axis of the Force vs. Time graph indicates elapsed time, while the vertical axis indicates the changing percentage of occlusal forces in both sides of the arch. The total force of the combined left and right arch halves is described in the Force vs. Time Graph by the non-vertical black line (Fig. 4).
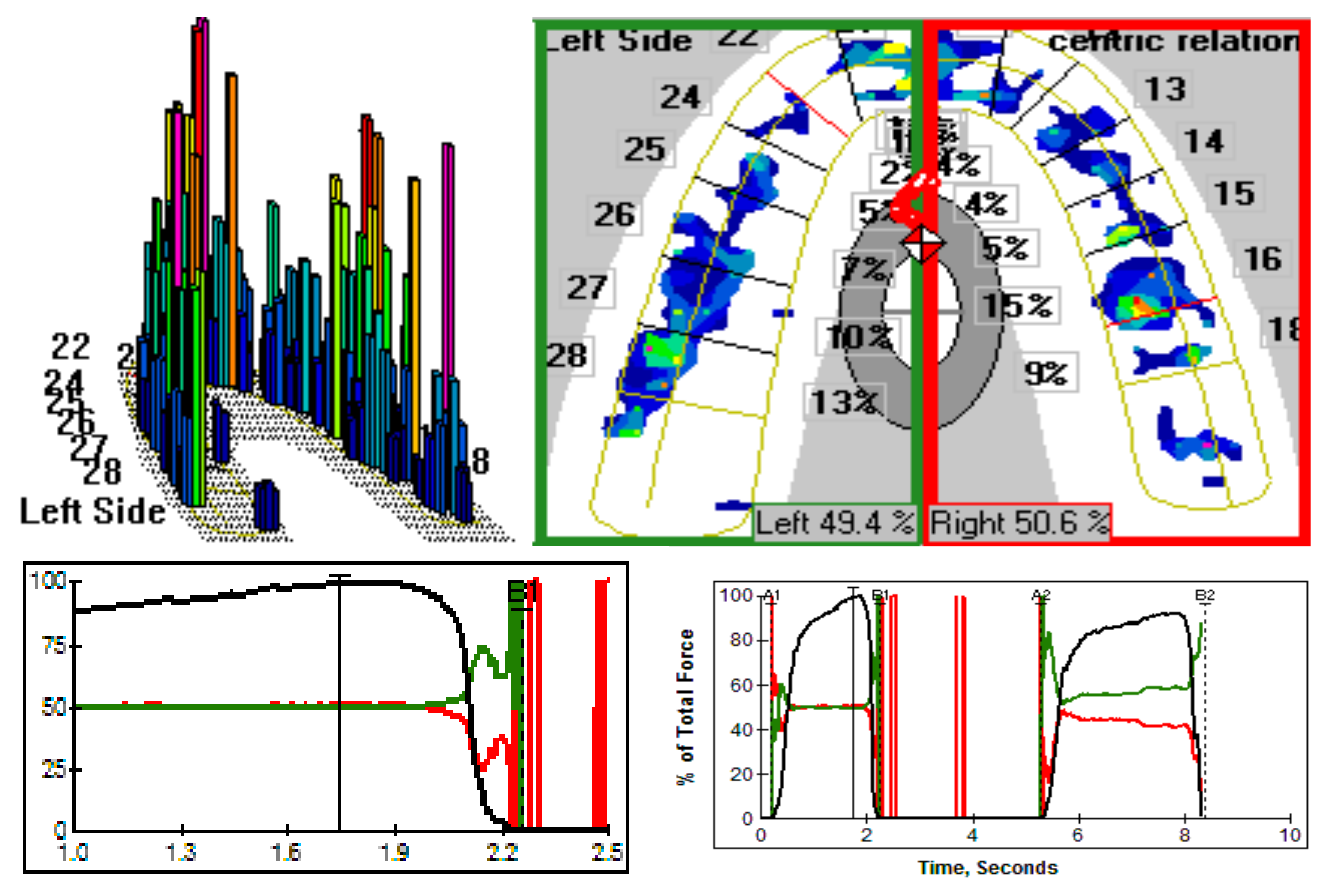

Figure 4 - Patient E. T., T-Scan III- system evaluation in centric relation, \% of Max Movie Force $(M M F), F=99.7 \%$

More precise information about each element in the dental arch and the absence of an element is accurately recorded when the sensor is adapted to the oral cavity. It measures the length and sensitivity of the recording presented as low, medium and high sensitivity. 
The sensor is placed between the central incisors, parallel with the occlusal plane. Because the sensor is more rigid than paper, for easier adaptation before starting recording some acts of mastication are done. Recorded forces are kept in the harddrives and are available for analysis [7].

T-Scan III analyses the occlusion contacts simultaneously, from the moment of the first occlusal contacts until the maximum intercuspidation, giving us a view of initial occlusal contacts, the order in which they appear and the amount of relative occlusal forces, which allows us to identify and locate any traumatic occlusal contacts [5].

Clinical application of computerized occlusal analysis with the T-Scan III system

Considering the fact that the determination of occlusal forces has a major role in the protocol of dental and facial rehabilitation, in this literature review we summarize the possibilities and ways of testing occlusal forces and present achievements of the modern use of the T-Scan III system.

So, in 2011, An W, Wang B and Bai Y. [8], using the T-Scan II, examined occlusal contacts during protrusion and lateral movements of the mandible in adolescent patients divided into two groups, subjects who achieved normal dentition after orthodontic treatment as an experimental group and subjects with normal occlusion as a control group. The prevalence of occlusal interferences in the posterior segment in the experimental group was high and most of them were on the second molars. The value of disclusion time during left lateral movements, right lateral movements and protrusion in the experimental group were longer than those in healthy adolescents and young adults with normal occlusion.

Studies of the dental system are an integral part of scientific disciplines that study the functional anatomy of the orofacial system. Considering the fact that overall dynamic occlusion affects the stomatognatic system, more emphasis is placed on the evaluation of functional occlusion details before completion of the orthodontic treatment. The presence of occlusal interferences increases the chance of disorders in the dental system.

For this purpose, He SZ, Li S, Gao XN and An WW [9]. performed evaluation of the occlusal contact characteristics changes with the T-Scan II system in participants divided into two groups, a non-occlusal interference group and an occlusal interference group. They concluded that absence of occlusal interference and decreasing the disclusion time significantly improves overall dynamic occlusion.

Koos B, Höller J, Schille C and Godt A. [1], using the T-Scan III; Cumdente, Tübingen, Germany appliance, performed an analysis of force relations in the dental arch over the course of time and in correlation with their antagonistic dental contact points. They assessed 190 masticatory cycles of 38 subjects with 5 repetitions each, analysing the first $0.15 \mathrm{~s}$ after the first recorded antagonistic tooth contact.

Analysing the occlusion over time they concluded that it is the central incisors that usually tend to come into initial contact, perhaps as the result of a guiding function. Over time, the force distribution shifts to the posterior. At t1, $44 \%$ of the subjects occluded first in the molar area, surprisingly, while another $40 \%$ occluded first on the anterior teeth. Simultaneous initial antagonistic tooth contact occurred in the lateral and anterior teeth in only $16 \%$. At t10 (after $0.1 \mathrm{~s}$ ); the predominant contact was in the molar and premolar region. The relative masticatory force distribution also changed over time, starting with a relatively large initial force on the central incisors towards the posterior at the conclusion of recording. In the lateral comparison (right/left), the force relationships likewise changed over time (t2 on the left $42.6 \%$ of the relative masticatory force, $57.4 \%$ on the right). By t 10 , this lateral difference was significantly reduced $(47.4 \%$ on the left, $52.6 \%$ on the right). The lateral difference, thus, decreased by $9.6 \%$ from $\mathrm{t} 2$ to 10 .

Koos B, Godt A, Schille C and Goz G. [11], in their study, tested the accuracy and reliability of an instrumentation-based method of analysing occlusion and its resulting distribution of forces in the dental arch. They concluded that the measuring technique studied is superior to the usual methods. A combination of this method with marking foils would be ideal because the pressure-sensitive foils in this system do not produce any contact markings intraorally. This combination enables the contacts depicted on the computer to be assigned intraorally with even greater precision.

Today there is an extensive literature descrybing the dental bone-muscular system. In this area, the data on the dental occlusal forces system occupy a relatively small place. Therefore, Kerstein RB and Radke J. investigated the correlation between muscle activity and the disclusion time. Forty-five symptomatic, fully informed subjects (29 female, 16 male) had their right and left disclusion times recorded with T-Scan III, while the bilateral masseter and anterior temporalis muscle activity was simultaneously recorded electromyographically with BioEMG III ( $\mathrm{n}=180$ muscles) [12]. They concluded that there is high significant activity reduction in all four muscles after shortening the pretreatment prolonged disclusion time to less than 0.4 seconds. Excursive muscle hyperactivity can be a source of lactic acid accumulation, muscular ischaemia, and chronic myalgic temporomandibular joint dysfunction (TMD) symptoms. 
Wang $\mathrm{C}$ and Yin $\mathrm{X}$. [13] performed an analysis of occlusal risk factors associated with temporomandibular disorders in thirty-one patients with complete natural dentition and Angle class I occlusion who exhibited TMD, compared with the 31 healthy control subjects. The occlusal registrations were performed using the T-Scan II occlusal imaging and analysis system. The centre of occlusal force, asymmetry index of occlusal force, maximal movement of COF, premature contacts, occlusion and disclusion time were recorded. Compared with the control subjects, the TMD subjects had a significantly higher frequency of premature contacts $(16 / 32,50.0 \%)$ and greater bilateral asymmetry in the occlusal force. Furthermore, prolonged occlusion time and disclusion time also were observed in the TMD subjects. These results suggest that a significant association exists between occlusal stability and TMD in young adults.

The etiology of temporomandibular disorder (TMD) is multifactorial $[15,16,18]$. Though occlusion is considered to play a bigger role in initiation of disorder, this is not being conclusively demonstrated. Mandibular dysfunction due to TMD is more a result of functional malocclusion than morphological malocclusion. Excessive load on the masticatory system due to occlusal instability eventually gives rise to temporomandibular damage. The influence of occlusion on the onset of TMD is debated, and still a source of controversy [10-14]. A detailed, exhaustive study of these factors will help in furthering the knowledge of the possible existence of the association. Correct understanding of dynamic occlusion is very critical in differrentiating between the normal and pathological occlusal parameters. Digital evaluation of the occlusion with the T-Scan system enables the clinician to evaluate the occlusal contacts quantitatively and record the occlusion during continuous mandibular movement and will provide additional information such as occlusion and disclusion time on functional occlusion [17].

\section{Conclusion}

One of the most important activities that needs to be undertaken is improving the management and the equipping of dental clinics with modern equipment and technology for the testing and rehabilitation of dentofacial disorders.

The introduction of a protocol for occlusal forces measurement should be integrated in all dental disciplines and dental clinics. In particular, the application of this method should be performed in all complex clinical cases.

Application and implementation in daily clinical practice of computerized occlusal analysis with the T-Scan system as a scientific discipline and strategy is incorporated in many states.

\section{REFERENCES}

1. Angle EH. Classification of malocclusion. Dental Cosmos. 1899; 41: 248-264.

2. Andrews LF. The six keys to normal occlusion. Am J Orthod. 1972; 62(3): 296-309.

3. Andrews LF, Andrews WA. The six elements of orofacial harmony. Andrews J. 2000; 1: 13-22.

4. Qadeer S, et al. Relationship between articulation paper mark size and percentage of force measured with computerized occlusal analysis. J Adv Prosthodont. 2012; 4(1): 7-12.

5. Dr. Jin-Hwan Kim, DDS Article 1. Computerized Occlusal Analysis Utilizing the T-Scan III System.

6. Julia Cohen-Lévy, Nicolas Cohen. Computerized occlusal analysis in dentofacial orthopedics: indications and clinical use of the T-scan III system. Journal of Dentofacial Anomalies and Orthodontics. Vol. 15, Issue 02, January 2012.

7. Baldini, A. Beraldi, A. Nanussi. Importanza clinica della valutazione computerizzata dell'occlusione. DENTAL CADMOS. 2009, April; 77(4).

8. An W, Wang B, Bai Y. Occlusal contacts during protrusion and lateral movements after orthodontic treatment. Hua Xi Kou Qiang Yi Za Zhi. 2011 Dec; 29(6): 614-7.

9. He Shu-zhen, Li Song, Gao Xiao-hui, An Wei-wei. A preliminary study on the occlusal contact changes during retention in adolescent patients. Chinese Journal of Stomatology. 2010; 45(9): 556-9.

10. Koos B, Höller J, Schille C, Godt A. Time-dependent analysis and representation of force distribution and occlusion contact in the masticatory cycle. J Orofac Orthop. 2012 May; 73(3): 204-14.

11. Koos B, Godt A, Schille C, Goz G. Precision of an instrumentation-based method of analyzing occlusion and its resulting distribution of forces in the dental arch. J Orofac Orthop. 2010 Nov; 71(6): 403-10.

12. Kerstein RB, Radke J. Masseter and temporalis excursive hyperactivity decreased by measured anterior guidance development. The Journal of Craniomandibular Practice, Publisher: Chroma, Inc. Audience: Academic Format: Magazine/Journal. 2012 Oct; 30(4): 243-54.

13. Wang $C, Y$ in $X$. Occlusal risk factors associated with temporomandibular disorders in young adults with normal occlusions. Oral Surg. Oral Med. Oral Patho. Radiol. 2012 Oct; 114(4): 419-23.

14. Ciancaglini R, Gherlone E.F., Radaelli G. Association between loss of occlusal support and symptoms of functional disturbances of the masticatory system. $\mathbf{J}$ Oral Rehabil. 1999; 26(3): 248-53.

15. Conti P.C, et al. A cross-sectional study of prevalence and etiology of signs and symptoms of temporomandibular disorders in high school and university students. J Orofac Pain.1996; 10(3): 254-62.

16. Marklund S, Wanman A. Risk factors associated with incidence and persistence of signs and symp- 
toms of temporomandibular disorders. Acta Odontol Scand. 2010 Sep; 68(5): 289-99.

17. Kahn J, Tallents RH, Katzberg RW, Ross ME, Murphy WC. Prevalence of dental occlusal variables and intraarticular temporomandibular disorders: molar relationship, lateral guidance, and nonworking side contacts. J Prosthet Dent. 1999 Oct; 82(4): 410-5.

18. Akoren AC, Karaagaclioglu L. Comparison of the electromyographic activity of individuals with canine guidance and group function occlusion. J Oral Rehabil. $1995 ; 22(1)$ : 73-7.

Р е 3 и м е

\section{T-SCAN III CИСТЕМ ДИЈАГНОСТИЧКА АЛАТКА ЗА ДИГИТАЛНА ОКЛУЗАЛНА АНАЛИЗА ВО ОРТОДОНЦИЈАТА - МОДЕРЕН ПРИСТАП}

\section{Весна Трпевска ${ }^{1}$, Гордана Ковачевска ${ }^{2}$, Алберто Бенедети ${ }^{3}$, Божидар Јорданов ${ }^{4}$}

${ }^{1}$ Клиника за ортодонција, ЈЗУ УСКЦ

„Свети Пантелејмон“, Стоматолошки факултет, Универзитет „Св. Кирил и Методиј“, Скопје, Р. Македонија

${ }^{2}$ Клиника за стоматолошка протетика, ЈЗУ УСКЦ „Св. Пантелејмон“, Стоматолошки факултет, Универзитет „Св. Кирил и Методиј“, Скопје, Р. Македонија ${ }^{3}$ ЈЗУ УК за максилофацијална хирургија, Стоматолошки факултет, Универзитет „Св. Кирил и Методиј“, Скопје, Р. Македонија ${ }^{4}$ Факултет за дентална медицина, Медицински универзитет, Софија, Катедра за стоматолошка протетика, Софија, Р. Бугарија

Вовед: Овој систематски ревиски труд е со цел да се утврди механизмот, методологијата, карактеристиките, клиничката апликација и мож- ностите на T-Scan III систем како дијагностичка алатка за дигитална оклузална анализа во различни полиња на стоматологијата, поточно на полето на ортодонцијата.

Методи: Беше направено пребарување на електронските бази MEDLINE and PubMed, рачно пребарување на релевантни списанија и скрининг на референтни листи на студиите што беа вклучени во пребарувањето без рестрикција на употребениот јазик. Публикациите што нудеа статистички обработени податоци беа вклучени во овој систематски ревиски труд.

Резултати: Дваесет потенцијални рандомизирани контролирани студии беа идентификувани. Само десет ги исполнуваа инклузионите критериуми. Литературата покажа дека употребата на дигитална оклузална анализа со T-Scan III систем во ортодонцијата има сигнификантни предности во поглед на нејзината способност за мерење на оклузалните параметри во статичка и динамичка позиција на мандибулата.

Заклучок: Може да се заклучи дека постојат докази што ја поддржуваат идејата дека T-Scan III систем е брза и точна алатка во идентификување на дистрибуцијата на оклузалните контакти и ветува како клиничко дијагностичко скрининг-средство за оклузија и подобрување на оклузијата по различни дентални третмани. Дополнителни клинички студии се потребни за да се унапреди полето на индикации на овој систем. Важноста од неговата употреба во ортодонцијата заслужува понатамошни испитувања.

Клучни зборови: ортодонтска терапија, скелетни дентофацијални неправилности, T-Scan III систем, дигитална оклузална анализа. 